\title{
THE COMPARATIVE ANALYSIS OF THE PICTURE OF THE WORLD IN THE ENGLISH AND FRENCH PHRASEOLOGY
}

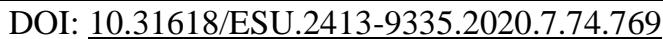 \\ Холмурадова Лейла Эшкуватовна \\ доктор философии (PhD), \\ доиент кафедры теории и практики перевода, \\ Самаркандский Институт Иностранных Языков, \\ г. Самарканд, Узбекистан.
}

\begin{abstract}
It is hard to deny the great number of similarities and commonalities in the English and French nations and their cultures. The analysis of English and French mentality showed that the uniqueness of the phraseological picture of the world in any language consists in the special correlation of the universal and the nation-specific. This can be easily seen in proverbs, which form a part of the cultural tradition of the peoples and reflect everyday life. Both the English and the French proverbs encourage people to respect their parents, bring up their children, value friendship and be attentive towards elders, reflecting the lofty concepts of honour and moral purity. The proverbs also condemn and mock human vices and weaknesses.

Research methods. The following methods of linguistic analysis were used in the work:

- the comparative method to identify the similarities and differences in the phraseological pictures of the world among the English and French peoples;

- the method of linguo-culturological analysis to identify the socio-cultural meanings that influenced the development of the English and French peoples;

- the continuous sampling method to make a qualitative and quantitative analysis of the phraseological units in question from all the idioms found in dictionaries.

The scientific novelty of the work_consists in the following:

1)this is the first comparative analysis of the cultural and linguistic interrelation between the English and French peoples and its impact on the formation of the picture of the world;

2)the work reveals the linguo-culturological essence of the phraseological pictures of the world in the English and French languages;

3)the work reveals the historical characteristics of the development of the Engish and French nations and their culture;

The practical value of the workconsists in the possibility to use the developed research method to analyse phraseological material in a wide range of languages. The obtained results can be used in courses in comparative linguistics, phraseology, linguistic culturology, cognitive linguistics and theory of intercultural communication, as well as at special seminars in lexicology and science of translation.

The credibility of the research results_is determined by some important factors, such as the scientific research base and obtainment of new results that broaden our views on the nature of phraseology.

The use of the research results. The results of the research were introduced in the courses named 'The conservation of the colour of a text in the course of the implementation of artistic translation,' The history and theory of translation' and 'The stylistics and analysis of text,' and were used at practical lessons in English at the Faculty of Science of Translation at the Samarkand State Institute of Foreign Languages
\end{abstract}

Key words: English, French, culture, proverbs, phraseology

There are a number of works by foreign scholars, such as A. V. Kunin, V. N. Teliy, E. M. Solodukho, N. N. Amosova, L. P. Smith, R. I. Yarantsev, V. P. Felitsin and V. M. Mokiyenko, R. Baldauf, B. Jernudd, M. Benson, A. Cohen, and Cowie, that deal with the comparison of the phraseological pictures of the world in the languages of various peoples around the world, which consists in the study of thematic and ideographic semantics of idioms and the establishment of their figurative and substantiational bases - the culturological sources that had formed their semantics. The researchers that studied the comparative typology include V. D. Arakin, V. G. Gak, Yu. P. Solodub and M. K. Golovanivskaya and others).

The analysis of these works showed that the uniqueness of the phraseological picture of the world in any language consists in the special correlation of the universal and the nation-specific.
The Uzbek linguistics features a number of research works studying the phraseological units of the Uzbek language. Among them are those dedicated to the History of Linguistic Typology (A. A. Abduazizov, A. M. Bushuy, 2006), Principles of Phraseology (M. I. Umarkhojayev, 1983), Functional Methodological Characteristics of the Phraseological Units in the Contemporary Uzbek Language (A. E. Mamatov, 1993) and others. There also are a number of works in the Uzbek linguistics, written by M. I. Umarkhojayev, A. M. Bushuy and others that study the structural and semantic characteristics of the phraseological units in the German and English languages in comparison with the Uzbek language.

The works mentioned above are highly important from the practical viewpoint, helping to find and analyse idioms in the Uzbek language equivalent to English phraseological units. However, there has been 
little study given to the comparison of the phraseology of the English and French languages, in spite of the facts that for a long time in the history French remained the principal language for most of the people living in the territory of present-day England and that the French language has become the second amplest source after the Bible for the formation of the English phraseological picture of the world. Hence, the significance of this research lies in the fact that this is the first attempt in our country to compare these languages.

In recent years the interest in the personal aspect in the study of a language grew in all scientific disciplines connected in this or that way with language. This concerns not only linguistics, but psychology, philosophy and linguistic didactics.

The human factor plays an important role in phraseology, as most of the phraseological expressions are associated with man and his activity. Man is constantly attempting to endow human traits on the objects of the external world, both animate and inanimate.

To study and analyse phraseological expressions requires a special method, as well as the use of data from other sciences, such as lexicology, grammar, stylistics, phonetics, history of language, history, philosophy, logic and country studies.

Like words, idioms, stable in composition and ready to be spoken, occupy an important place in the linguistic section of man's mind. They are distinguished by integrity and figurativeness of meaning. Phraseology has to be studied, so that one can know how it reflects the national culture, as the phraseological units (PU) of this or that language bear imprinted on them the incredible diversity of the world of human traits and emotions, such as happiness, love, astonishment, mockery, indignation, interest, concern, suffering, straightforwardness, will, honesty, kindness, wit, dexterity, enthusiasm, persistence, silliness, talkativeness, greed, malice, success and failure,truth and lie, order and disorder, wealth and poverty, errors, punishment and many other things. Thus, we have a whole phraseological picture of the world.

When studying the status of the culture of the human society it is highly important to solve the question of the character of the connection between the language and thinking. Man stands between the language and the world. As he has realised these or those processes and understood their results, man transmits them to other members of his society using his language. Therefore, there is thinking between the language and reality.

Traditionally, we identify two types of thinking: concrete and abstract. Man's ability to symbolise is what distinguishes qualitatively his thinking from that of all other creatures. The word is a universal symbol, although it is not the only one. Man cannot recollect the complex or happy happenings of his life without shaping them into speech.

We believe that differences in languages are not often reflected in the manner different peoples behave, which is often because, when we study a language, we at the same time study the culture of the nation speaking this language. People always learn a foreign language and attempt to speak it in the context of a number of different cultures. We believe that it is impossible to improve the culture without improving the language, which is why language is a very interesting subject for people engaged in cultural research. Language records objects important for the bearers of this culture. The picture of the world in a language reflects the characteristic features and reality. Each fragment of the world is reflected in a language in the form of a word. In this case it is important to classify language units because of the necessity to record the meaning they bear beyond the linguistic categories. The dictionary that registers semantic relations between its components is called a thesaurus.

We also believe that the picture of the world represented in a language using phraseological means is reflected in the structure of the phraseological thesaurus, which is composed of phraseological units systematised according to the thematic and ideographic principle.

Taking the French picture of the world as a form of reflection of the objective reality and the systematic relations between the characteristic features of the nation in the mind of the native speakers, we use two approaches to a phraseological unit in our research: the gnoseological approach, which participates in the formation of an idiom's integral meaning, and the linguistic approach, which makes it possible to see the linguistic mechanisms of phrase formation.

The people's cultural and national selfconsciousness reflected in its phraseological stock plays an important part in this process. Like phraseological units, parables belong to the area of language that explicates cultural semantics. Each generation of the English and French peoples watched the world and the social and family relations and accumulated information: these results of observation are reflected in the traditional folk poetry. It is evident that no other genre of folklore reflects the life of people in such a deep and many-sided way, as parable do it. We think that they can easily be called an encyclopaedia of people's life, as they contain memories about a great number of historical events and facts.

Most proverbs contain figurative meanings based on the generalisation of single facts, which often makes it possible to interpret even proverbs with direct substantiation of meaning more broadly. For many years proverbs have been the focus of a number of folklorists, linguists and other scholars, which is the result of the uncertainty of a proverb's nature. Contemporary linguistics does not yet have a universal view on proverbs and sayings. Generally, proverbs are regarded as figurative sayings (usually a characteristic of a particular nation) typifying diverse aspects of life and having the form of a finished sentence. In our opinion, a proverb expresses a general opinion, while a saying conveys a partial argument. A linguistic symbol with a complex structure, a proverb has a general meaning and an inner form.

People can communicate with each other only because there is a common linguistic system. Proverbs 
form a certain part of this system - they can be used depending on the situation and, at the same time, retain their meaning.

The problem of studying the meaning of a proverb is largely a part of the general problem of correlation between meaning and theory. Within our work the meaning of a proverb implies the referential meaning. Despite the expressiveness and deep meaning proverbs and sayings contain, texts remain the most valuable keepers of culture. Texts reflect man's spiritual world and his culture.

The history of the English and French phraseology is directly dependent on the perception of the world by the English and French person. The French are known for their love for luxury, as well as by their fine taste and charm:

trendsetter;

arbitre des elegances (or $d u$ goût) (Fr.) -

faire ses délices de qch. (Fr.) - find greatest delight in something;

bouche delicate (Fr.)-gourmet;

avoir le palais fin (or délicat) (Fr.) - have a delicate taste;

le vert galant-lady-killer

soutenu (or élevé, noble) style-lofty style

The Englishmen are stiff and puritan and often like to embark on boring conversations about weather. Many of the English idioms relate these subjects:

king's weather-wonderful weather;

after rain comes fair weather (proverb) - after grief comes happiness;

the rain comes down in torrents;

rain or shine - whatever may happen.

Using this or that idiom, the Englishmen fill it with irony, thus assuring us that the English humour can show itself in situations you never expect it. For example: 'Partake of His Majesty's hospitality' (iron. coll. 'be in prison').

As the phraseological picture of the world consists of idioms that form fragments of the objective world, we used the thematic and ideographic concept as the basic principle of classification of idioms.

The phraseological picture of the world is defined as the knowledge of the world at the everyday level, which is why it often represents the "naïve picture of the world.' Set expressions contain fragments of ordinary reality, such as condition, action, quality, quantity, degree, situation and so on, which afterwards are reconsidered so that only essential links remain in them. These situations become the stereotypes of human behavior, conditioned by their cultural and national worldview.

The phraseological picture of the world is characterised by a number of distinguishing features, which impact greatly the formation of its semantic structure. We suppose that the following components are the most important.

Universality

Because the very fact of existence of phraseology is a language universal: there is no language that has no idioms in it.

Anthropocentrism
Humans and their perception of the world and reality stand in the centre of the linguistic picture of the world, which is why a person - their body, feelings, conditions, demands and interest - is the main scale of values. The human perceives the world around him or her filtering it through their own being.

The ontological and value anthropocentrism is reflected in language in the following way:

1) choosing a definite 'reference point,' that is, choosing the ground for the interpretation of the world's characteristic features;

2) in the characteristic of their level of value.

Thus, the phraseological picture of the world is a figurative model of the world, in which man thinks of himself as a part of the reality and of all other things around him as the reflection of his being.

3) Expressiveness

One of the distinguishing features of the phraseological picture of the world is its expressiveness or its expressive and figurative qualities.

We decided to find out how these microcomponents of connotation (figurativeness and reality) are used in the idiomatic semantics and how they influence the formation of the semantic space of the phraseological picture of the world in general.

figurativeness

An idiom is always (or almost always) is based on the comparison of the features of the linguistic reality, which become a standard, an example or, on the contrary, anti-standard of ideal quality, condition, action, situation and so on. Example: the devil knows many things because he is old.

All this allows us to conclude that the phraseological picture of the world is a universal figurative system of special 'linguistic' units, essential to all languages, which convey the characteristic features of the national mentality. It is characterised by distinguishing features, such as universality, anthropocentrism and expressiveness, the last one including figurativeness and modality.

Given below are French proverbs, which, slightly changed, can be found in the English language as well:

1)C'est dans la nécessité que l'on connaît ses vrais amis (Fr.)/ A friend in need is a friend indeed (Eng.);

2)Chien qui aboie, ne mord pas (Fr.) / Barking dogs seldom bite (Eng.).

These examples show how close are the French and English proverbs, as even the ways they are formulated in are the same in many cases. This commonality is completely natural. Proverbs reflect the people's wisdom, which had been accumulated for many centuries and which knows no borders or linguistic restrictions.

Since very ancient times proverbs have lived in the language, disclosing in a special way the people's intellect and the national psychology, history, life and worldview. People embodied the ideas of diligence, humanism, duty, honour, patriotism and heroism in the figurative and expressive sayings. Having brought the proverbs through the centuries, people themselves determined their value and beauty. 
Reference:

1. Bushuy A.M. Ocherki o fraseologicheskoy I fraseograficheskoy koncepcii professora Muhtara Umarhodjaeva - Andijan: 2009.

2. Kunin A.V. Fraseologiya sovremennogo angliyskogo yazika. M.: 1972.

3. Mamatov A. E. Vajnoe uchebnoe posobie po francuzckoy fraseologii. Sb. Nauch.statey. Tashkent, 2013. C.197-202.
4. French - Russian Phraseological Dictionary M.,2006.

5. English - Russian Phraseological Dictionary M.,1984.-944c.

6. Robert Byrne. 1,911 Best Things Anybody Ever Said. New York, 1998. 